\title{
PENGARUH PENGAMALAN DZIKIR ASMAA-UL HUSNA TERHADAP PENINGKATAN KINERJA KARYAWAN PADA INDUSTRI MANUFAKTUR DI YOGYAKARTA TAHUN 2016
}

\author{
Dinik Fitri Rahajeng Pangestuti dan Kristantyo Setiyo Hari Purnomo
}

\begin{abstract}
Performance problem is a problem that is many researched because the performance is the most critical aspect in the sustainability of an organization. Employees ditching, waste of resources, embezzlement, boredom and lazy is a performance problem that must be sought out the causes and solutions. Asmaa-ul Husnaa is believed as the secret door to open the sciences of Allah, which will lead us down the Alloh pathway. If the practice and understanding of Asmaa-ul Husnaa applied in employment, the employee will have a great performance by way according to the terms and conditions as taught by ulama. This study aims to provide an alternative solution on how to provide guidance to employees fundamentally with Asmaaul Husna dhikr so that the employee's performance will continue to increase over time in line with increasing sincerity to work for Allah, was always supervised Allah and closeness to Allah who gave birth peace and fullfilness because of an abundance of grace and forgiveness. This research is a kind of explanatory research or hypothesis testing research, this research aims to explain certain kinds of relationships, influence, or set differences between groups or independence of two or more in an object studied. Data was gathered by experiment method that intervention in the research subjects through the practice of dhikr, then take measurements and observations post-practice routine to know the influence on employee performance. Expected results of the research can be a book so it can be an alternative solution to the problems faced by the company's performance.
\end{abstract}

Keyword : asmaa-ul husnaa, dzikr, peace, performance

\section{PENDAHULUAN}

Permasalahan kinerja merupakan permasalahan yang banyak diteliti karena kinerja merupakan aspek yang paling penting di dalam keberlangsungan suatu organisasi. Karyawan membolos, pemborosan sumber daya, penggelapan uang, rasa bosan dan malas merupakan permasalahan kinerja yang harus dicari tahu penyebab dan solusinya.

Karyawan yang memiliki kinerja yang unggul merupakan impian bagi semua perusahaan. Karyawan menjadi brainware sekaligus aktor utama bagi sistem perusahaan. Bagaimanakah aktor ini seharusnya dalam memainkan peran di dalam sistem besar tersebut.

"Bacalah dengan (menyebut) nama Tuhanmu yang menciptakan, Dia telah menciptakan manusia dari segumpal darah. Bacalah, dan Tuhanmulah Yang Maha Mulia, yang mengajarkan manusia dengan pena. Dia mengajarkan kepada manusia apa yang tidak diketahuinya." (Q.S Al 'Alaq : 1-5). Ayat ini merupakan ayat yang pertama kali diturunkan kepada Rasululloh SAW, yang merupakan pertanda bahwa beliau merupakan insan yang dipilih untuk mengemban tugas kerasulan, yaitu membawa pesan kerahmatan bagi seluruh alam (rahmatan lil alamin). Di dalam ayat tersebut tersimpan pesan agung tentang bagaimana seharusnya kita berjalan di muka bumi ini dengan profesi kita masing-masing. "Dia mengajarkan kepada manusia apa yang tidak diketahuinya" (Q.S Al 'Alaq : 5), namun ada syaratnya yaitu "Bacalah dengan (menyebut) nama Tuhanmu yang menciptakan, Dia telah menciptakan manusia dari segumpal darah. Bacalah, dan Tuhanmulah Yang Maha Mulia, yang mengajarkan manusia dengan pena.” (Q.SAl 'Alaq : 1 - 4). 
Para ulama sepakat bahwa cahaya Alloh terus dan selalu terpancarkan untuk seluruh alam, inilah bukti bahwa pengajaran Alloh terus berlangsung sepanjang waktu. Bagaimana biji dapat menumbuhkan tunasnya, serbuk sari dapat membuahi putik sehingga bunga dapat menjadi buah, sperma dapat mendatangi ovum hingga menjadi janin yang tumbuh menjadi manusia dewasa dan masih banyak lagi bukti lainnya. Ada energi cerdas di balik keberlangsungan tersebut. Energi cerdas yang begitu kuat memancar. Energi cerdas yang bekerja dengan lembut, detil dan cermat. Energi ke-Tuhanan. Bagaimanakah cara terbaik dalam menyebut nama Tuhan yang menciptakan tersebut? Supaya kita selalu diajarkan atas apa-apa yang tidak kita ketahui? Al Qur'an pun telah mengajarkannya, yaitu "Hanya milik Alloh asmaul husna, maka berdoalah kepadaNya dengan menyebut asmaul husna itu. Dan tinggalkanlah orang-orang yang menyimpang dari kebenaran dalam (menyebut) nama-nama-Nya. Kelak mereka akan mendapat balasan terhadap apa yang telah mereka kerjakan." (Q.S. Al A'raaf : 180). Maka Asmaa-ul Husnaa merupakan pintu rahasia terbukanya ilmu-ilmu Alloh, yang akan menuntun kita menuju jalan yang dikehendaki-Nya. Jika pengamalan dan pemahaman Asmaul Husna ini diterapkan di dalam pekerjaan maka karyawan akan memiliki kinerja yang unggul dengan syarat dan ketentuan seperti yang diajarkan para ulama.

Penelitian ini bertujuan untuk memberikan alternatif solusi bagaimana melakukan pembinaan kepada karyawan secara mendasar dengan dzikir Asmaul Husna. Selain itu sebagai langkah awal pembiasaan diri untuk selalu melibatkan Sang Pencipta kita dalam setiap gerak kehidupan kita. Diharapkan para responden merasakan manfaat positif dari dzikir Asmaul Husna sehingga akan tetap melakukannya meskipun penelitian sudah berakhir.

\section{Al Asmaa-ul Husnaa}

Pengertian Al Asmaa-ul Husnaa menurut arti kebahasaan yaitu nama-nama Alloh yang bagus-bagus. Al Asmaa-ul Husnaa adalah nama-nama Alloh yang diperintahkan untuk dibaca ketika berdoa sesuai dengan firman-Nya dalam surat Al A'raaf ayat 180, "Hanya milik Alloh asmaul husna, maka berdoalah kepadaNya dengan menyebut asmaul husna itu. Dan tinggalkanlah orang-orang yang menyimpang dari kebenaran dalam (menyebut) nama-nama-Nya. Kelak mereka akan mendapat balasan terhadap apa yang telah mereka kerjakan." (Q.S. Al A'raaf : 180).

Manusia merupakan penggerak utama di dalam setiap sendi kehidupan. Namun di dalam diri manusia terdapat potensi-potensi kebaikan sekaligus keburukan, seperti yang diisyaratkan dalam Q.S Asy Syams ayat 7-10, “...demi jiwa serta penyempurnaan ciptaannya. Maka Dia mengilhamkan kepadanya (jalan) kejahatan dan ketakwaannya, sungguh beruntung orang yang mensucikannya (jiwa itu). Dan sungguh rugi orang yang mengotorinya." Dari ayat ini ada isyarat mengenai potensi keburukan dalam diri manusia. Sebagai brainware, peran manusia dalam menjadikan baik buruknya sesuatu sangat besar. Maka jika kita menginginkan suatu kebaikan, yang harus dibenahi terlebih dahulu adalah aspek brainware. Dalam peradaban manusia, role model terbaik adalah Nabi Muhammad SAW dengan akhlaknya yang membawa pengaruh sangat besar dalam peradaban dunia hingga saat ini. Bahkan Alloh memuji beliau dalam Q.S Al Qalam: 4 yang berbunyi, "Dan sesungguhnya kamu benar-benar berbudi pekerti yang agung."

Rasulullah SAW adalah pribadi yang memiliki kinerja terbaik sepanjang masa. Peninggalan dari kinerja Rasululloh SAW masih terpatri dengan kuat baik yang berupa bentuk peribadahan, tata cara dalam kehidupan, kepiawaian dalam kepemimpinan dalam tata negara, dalam peperangan, dalam pendidikan, dalam masyarakat, dalam misi perdagangan serta dalam keluarga (Antonio, 2008). Fungsi Asmaa-ul Husnaa adalah sebagai Media Taqorrub Ilalloh (mendekatkan diri kepada Alloh). Dengan terus mendekatkan diri kepada Alloh maka akhlak tercela sedikit demi sedikit akan hilang dan akhlak terpuji sedikit demi sedikit akan muncul (Al Hafidh, 2014).

Pengaruh Pengamalan Dzikir Asmaa-Ul Husna terhadap Peningkatan Kinerja Karyawan pada Industri Manufaktur 
Melakukan aktivitas dzikir secara rutin akan melahirkan ketenteraman hati, seperti yang dijanjikan Alloh dalam Q.S. Ar Raa'du : 28 yang berbunyi sebagai berikut, "(yaitu) orang-orang yang beriman dan hati mereka menjadi tenteram dengan mengingat Alloh. Ingatlah, hanya dengan mengingat Alloh hati menjadi tenteram." Orang yang melakukan aktivitas dzikir atau mengingat Alloh juga akan melahirkan kedekatan kepada Alloh sehingga Alloh akan melimpahkan rahmat dan ampunan karena orang tersebut berada dalam ingatan Alloh, seperti yang terdapat di dalam Q.S. Al Baqarah : 152, "Maka ingatlah kepadaKu, Aku pun akan ingat kepadamu bersyukurlah kepadaKu dan janganlah kamu ingkar kepadaKu."

Berdasarkan HR Tirmidzi juz 5 halaman 193 nomor hadist 3575, Rasululloh bersabda, "Sesungguhnya Alloh mempunyai 99 nama, barang siapa hafal (membaca setiap hari) akan masuk surga."(Al Hafidh, 2014). Rincian dari 99 nama tersebut telah dihimpun oleh para alim ulama berdasarkan suatu metode khusus, yaitu: Ar Rohmaan, Ar Rohiim, Al Malik, Al Quddus, As Salaam, Al Mu'min, Al Muhaimin, Al Aziz, Al Jabbaar, Al Mutakabbir, Al Khaaliq, Ar Baari', Al Mushawwir, Al Ghofar, Al Qohhar, Al Wahhab, Ar Razaaq, Al Fattaah, Al 'Alim, Al Qobidl, Al Baasith, Al Khaafidl, Ar Raafi', Al Mu'iz, Al Mudzil, As Sami', Al Bashiir, Al Hakam, Al A'dlu, Al Latiif, Al Khabiir, Al Haliim, Al Adhiim, Al Ghofuur, Asy Syakuur, Al Aliyy, Al Kabiir, Al Hafidh, Al Muqiit, Al Hasiib, Al Jaliil, Al Kariim, Ar Roqiibu, Al Mujiib, Al Waasi', AL Hakiim, Al Wadudu, Al Majiid, Al Baaits, Asy Syahiid, Al Haqq, Al Wakiil, Al Qowwiy, Al Matiin, Al Waliyy, Al Hamid, Al Muhshii, Al Mubdi', Al Muhyii, Al Mumiit, Al Hayyu, Al Qoyyum, Al Waajid, Al Maajid, Al Wahiid, Al Ahad, Ash Shomad, Al Qaadir, Al Muqtadir, Al Muqoddim, Al Muakhir, Al Awwal, Al Akhir, Adh Dhohiir, Al Batiin, Al Waaly, Al Muta'aaly, Al Baaru, At Tawwabu, Al Muntaqim, Al Afuw, Ar Raufuu, Maalikul Mulki, Dzal Jalaali wal Ikraam, Al Muqsit, Al Jaami', Al Ghoniy, Al Mughnii, Al Maani', Adh Dhaar, An Naafi', An Nuur, Al Hadii, Al Badii', Al Baaqi, Al Waarits, Ar Rosyiid, Ash Shobuur. ${ }^{1}$

\section{Kinerja dalam Perspektif Al Qur'an}

Di dalam Al Qur'an Alloh memberikan kemuliaan-kemuliaan kepada hambanya yang memiliki kinerja baik, yang mengisi kehidupannya dengan perbuatan baik seperti yang terdapat dalam Q.S Al Baqarah : 148 "Dan setiap umat mempunyai kiblat yang dia menghadap kepadanya. Maka berlomba-lombalah kamu dalam kebaikan. Di mana saja kamu berada pasti Alloh akan mengumpulkan kamu semuanya. Sungguh, Alloh Maha Kuasa atas segala sesuatu.” Atas kinerja tersebut maka Alloh akan memberikan balasan. "Balasan bagi mereka ialah ampunan dari Tuhan mereka dan surga-surga yang mengalir di bawahnya sungai-sungai, mereka kekal di dalamnya. Dan (itulah) sebaik-baik pahala bagi orang yang beramal (Q.S. Ali Imron:136).” Mereka mendapatkan kehormatan dan ditempatkan di dalam alam 'ulwi seperti yang tersurat di dalam Q.S Ali Imron : 139 “Dan janganlah kamu merasai lemah, dan jangan (pula) bersedih hati, sebab kamu paling tinggi (derajatnya), jika kamu orang beriman."

Sebutan kepada hamba yang telah memiliki kinerja ke-Tuhanan yang tinggi yaitu: shidiqin, syuhada, sholihin, muslimin, muslimat, mukminin, mukminat,qonitin, qonitat,shodiqin, shodiqot, shobirin, shobirot, khosyi'in, khosyi'at, mutashodiqin, mutashodiqot, shoimin, shoimat, khafithin, khafithat, dzakirin, dzakirot,taibiin, taibat, tawwabin, hamidin, saihin, roki'in, saajidin.

\footnotetext{
1 Sulaiman al-Asyqar, Umar. Edisi Indonesia: Al-Asma' al-Husna.Jakarta: Qisthi Press, 2010, h. 105.
} 


\section{Kinerja dalam Perspektif Modern \\ Pengertian Kinerja}

Kinerja dalam bahasa inggris disebut job performance atau actual performance atau level performance, yang merupakan tingkat keberhasilan pegawai dalam menyelesaikan pekerjaannya. Kinerja bukan merupakan karekteristik individu seperti bakat atau kemampuan namun merupakan perwujudan dari bakat atau kemampuan itu sendiri serta hasil kerja yang yang dicapai pegawai dalam mengemban tugas dan pekerjaan yang berasal dari organisasi. ${ }^{2}$

Performance atau kinerja adalah hasil yang dapat dicapai oleh seseorang atau kelompok orang dalam suatu organisasi, sesuai dengan wewenang dan tanggung jawab masing-masing, dalam rangka upaya mencapai tujuan organisasi bersangkutan secara legal, tidak melanggar hukum dan sesuai dengan moral maupun etika. ${ }^{3}$

Menurut Bernandin \& Russell Kinerja (Performance) adalah catatan outcome yang dihasilkan dari fungsi suatu pekerjaan tertentu atau kegiatan selama suatu periode waktu tertentu. 4

\section{Faktor-faktor yang Mempengaruhi Kinerja}

Terdapat banyak pakar yang menguraikan faktor-faktor yang mempengaruhi kinerja. Menurut Gibson, Ivancevich dan Donnely menyatakan bahwa faktor-faktor yang mempengaruhi kinerja pegawai adalah variabel individu, variabel psikologi, maupun variabel organisasi. Variabel individu meliputi kemampuan dan keterampilan baik fisik maupun mental; latar belakang, keluarga, tingkat sosial dan pengalaman; demografi, menyangkut umur, asal usul dan jenis kelamin. Variabel psikologis meliputi persepsi, sikap, kepribadian, belajar motivasi. Variabel organisasi meliputi sumber daya, kepemimpinan, imbalan, struktur dan desain pekerjaan. ${ }^{5}$

\section{Penilaian Kinerja}

Menurut Bernandin dan Russell kriteria untuk menilai kinerja karyawan adalah sebagai berikut. 6

1) Quantity Of Work (Kuantitas Kerja): jumlah kerja yang dilakukan dalam suatu periode yang ditentukan.

2) Quality Of Work (Kualitas Kerja): kualitas kerja yang dicapai berdasarkan syarat-syarat kesesuaian dan ditentukan.

3) Job Knowledge (Pengetahuan Pekerjaan): luasnya pengetahuan mengenai pekerjaan dan keterampilannya.

4) Creativeness (Kreativitas): keaslian gagasan yang dimunculkan dan tindakan-tindakan untuk menyelesaikan persoalan-persoalan yang timbul.

5) Cooperation (Kerjasama): kesediaan untuk bekerjasama dengan orang lain atau sesama anggota organisasi.

6) Dependability (Ketergantungan): kesadaran untuk mendapatkan kepercayaan dalam hal kehadiran dan penyelesaian kerja.

7) Initiative (Inisiatif): Semangat untuk melaksanakan tugas-tugas baru dalam memperbesar tanggung jawabnya.

8) Personal Qualities (Kualitas Personal): Menyangkut kepribadian, kepemimpinan, keramahtamahan dan intergritas pribadi.

\footnotetext{
2 Priansa, Donni. Perencanaan dan pengembangan SDM. Alfabeta. Bandung. 2014, h. 98.

3 Prawirosentono, Suyadi. Kebijakan Kinerja Karyawan. BPFE. Yogyakarta. 1999, h. 2.

4 Gomes. Manajemen Sumber Daya Manusia. Andi Offset. Yogyakarta. 2003, h. 52.

5 Riani, Asri Laksmini. Budaya organisasi Edisi Pertama. Yogyakarta : Graha Ilmu. 2011, h. 85

6 Ibid., h. 89.
} 


\section{Tujuan Penilaian Kinerja}

Werther dan Davis menyatakan bahwa beberapa tujuan dari pelaksanaan penilaian terhadap pegawai yang dilakukan organisasi adalah peningkatan kinerja; penyesuaian kompensasi; keputusan penempatan; kebutuhan pengembangan dan pelatihan; perencanaan dan pengembangan karir; prosedur perekrutan; kesalahan desain pekerjaan dan ketidakakuratan informasi; kesempatan yang sama; tantangan eksternal; dan umpan balik.7

\section{Manfaat Penilaian Kinerja}

Penilaian kinerja adalah proses penilaian hasil kerja yang akan digunakan oleh pihak manajemen untuk memberi informasi kepada karyawan secara individual, tentang mutu hasil pekerjaannya dipandang dari susut pandang kepentingan perusahaan. ${ }^{8}$

Tujuan kinerja (Performance) secara umum dibedakan atas dua macam, yaitu: (1) Untuk mereward performance sebelumnya, dan (2) Untuk memotivasikan perbaikan performance pada waktu yang akan datang .9

\section{Metode Penilaian Kinerja}

Metode penilaian kinerja ada dua macam yaitu (Sunarto, 2001:89) yaitu sebagai berikut.10

\section{- Metode Berorientasi Masa Lalu}

Metode ini mempunyai kelebihan dalam hal perlakuan terhadap prestasi kerja yang telah terjadi yang dapat diukur, sehingga paling tidak para pegawai mempunyai umpan balik mengenai usaha mereka. Teknik yang digunakan dalam metode ini antara lain:

Rating Scale, metode ini evaluasi subyektif dilakukan penilai terhadap prestasi kerja pegawai dengan skala tertentudari rendah sampai tinggi. Evaluasi hanya didasarkan pada pendapat penilai yang membandingkan hasil pekerjaan dengan faktor-faktor yang dianggap penting bagi pelaksanaan pekerjaan tersebut.

Checklist, penilai biasanya adalah atasan langsung tapi tanpa diketahui oleh pegawai yang dinilai. Dalam metode ini penilai tinggal memilih kalimat atau kata yang menggambarkan prestasi kerja dan karakteristik pegawai.

Peristiwa Kritis, metode ini mendasarkan pada catatan penilai yang menggambarkan perilaku pegawai sangat baik atau sangat jelek dalam kaitannya dengan pelaksanaan kerja, yang disebut dengan peristiwa kritis. Metode ini sangat berguna dalam memberikan umpan balik kepada pegawai dan mengurangi kesalahan kesan terakhir.

Tes dan Observasi Prestasi Kerja, bila jumlah pekerjaan terbatas, penilaian kinerja bisa didasarkan pada tes pengetahuan dan ketrampilan. Agar berguna tes harus variabel dan valid.

Evaluasi Kelompok, dalam metode ini ada beberapa teknik penilaian yaitu :

- Metode Ranking, penilai membandingkan pegawai yang satu dengan pegawai yang lain untuk menentukan siapa yang lebih kemudian menempatkan dalam urutan dari mana yang terbaik sampai yang terburuk.

- Grading atau Forced Distribution, penilai memisahkan para pegawai ke dalam berbagai klasifikasi yang berbeda.

- Point Allocation Method, metode ini merupakan bentuk lain metode grading dimana penilai memberikan sejumlah nilai total untuk mengalokasikan diantara para pegawai

\footnotetext{
7 Ibid.

8 Prawirosentono, Suyadi. Kebijakan Kinerja Karyawan. BPFE. Yogyakarta. 1999, 25.

9 Gomes. Manajemen Sumber Daya Manusia. Andi Offset. Yogyakarta. 2003.

10Umar, Husein. Evaluasi Kinerja Perusahaan. Gramedia Pustaka Utama. Jakarta. 2002, h. 89.
} 
dalam kelompok. Para pegawai yang lebih baik diberi nilai yang lebih besar dari pada pegawai berprestasi jelek.

- Metode peninjauan lapangan (Field Review Method), metode ini, wakil ahli departemen SDM turun ke lapangan dan membantu penyelia dalam penilaian. Spesialis SDM mendapatkan informasi dari khusus dari atasan langsung tentang kinerja karyawan.

\section{- Metode Berorientasi Masa Depan}

Metode ini memusatkan kinerja pegawai di waktu yang akan datang melalui penilaian potensi pegawai atau melalui penetapan sasaran prestasi di masa datang. Teknik-teknik yang digunakan adalah: ${ }^{11}$

Penilaian Diri (Self Appraisals), teknik evaluasi ini berguna bila tujuan evaluasi adalah untuk melanjutkan pengembangan diri. Bila pegawai menilai dirinya, perilaku defensive cenderung tidak terjadi.

Penilaian Psikologis (Psychological appraisals), penilaian ini terdiri dari wawancara mendalam, tes psikologis, diskusi, dengan atasan langsung dan review evaluasi lainnya. Penilaian biasanya dilakukan oleh para psikologis, terutama digunakan untuk menilai potensi di masa mendatang.

Pendekatan Management By Objective (MBO), inti dari pendekatan ini adalah bahwa setiap pegawai dan penyelia secara bersama menetapkan tujuan dan sasaran pelaksanaan kerja di waktu yang akan datang. Kemudian dengan sasaran tersebut, penilaian kinerja dilakukan secara bersama pula.

\section{METODE}

Dalam penelitian ini, penulis mencoba menganalisis apakah variabel independen yaitu Asmaa ul Husna berpengaruh terhadap variabel dependen yaitu 4 dari 8 dimensi kinerja (Quality of Work, Quantity of Work, Job Knowledge, Creativeness) yaitu Rancangan tersebut di gambarkan dalam Gambar 1.

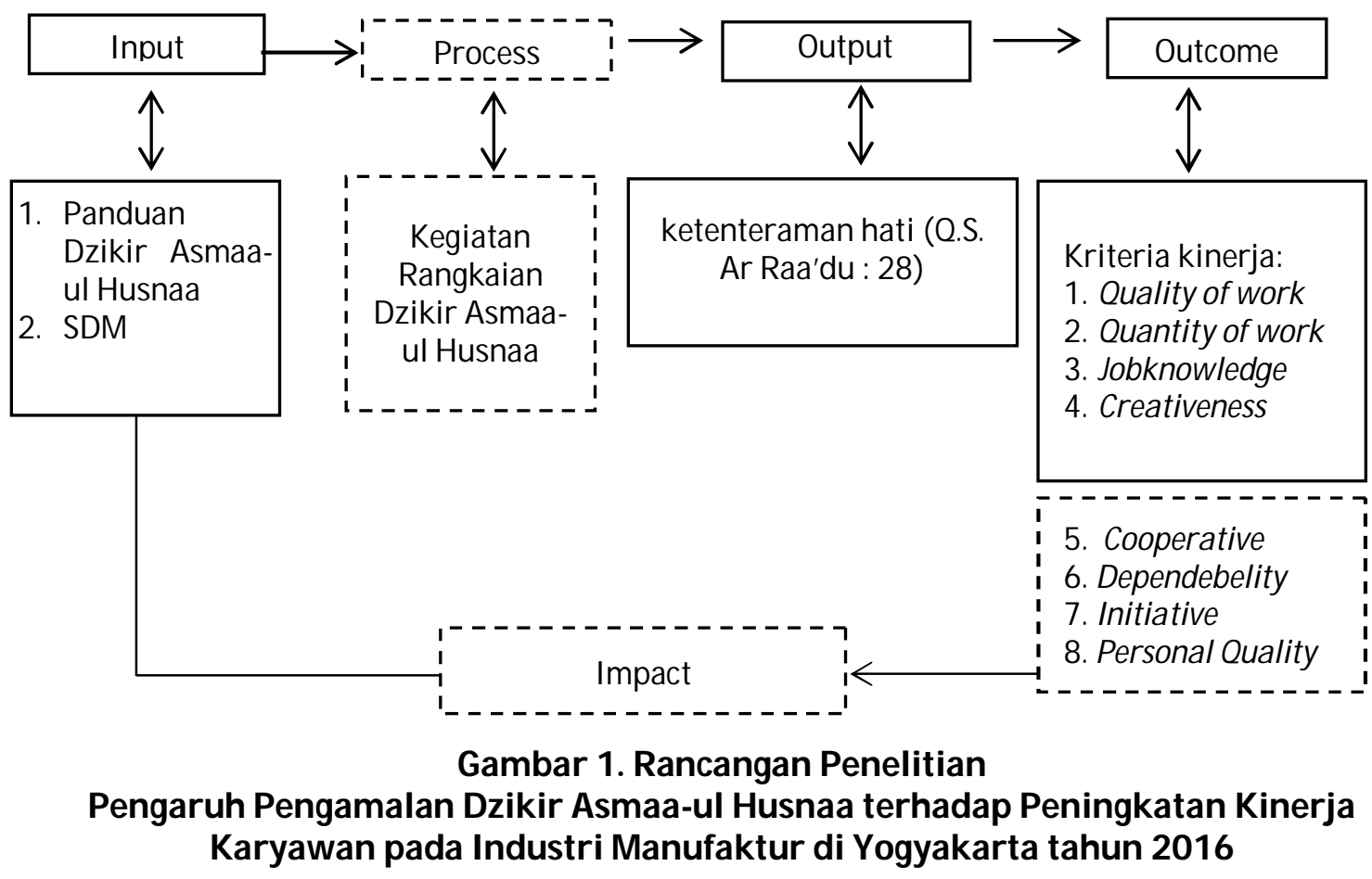

11Ibid., h. 15.

Pengaruh Pengamalan Dzikir Asmaa-Ul Husna terhadap Peningkatan Kinerja Karyawan pada Industri Manufaktur 
Keterangan :

Variabel yang diteliti
Variabel yang tidak diteliti

Pada bagian input berisi SDM sebagai subjek penelitian dan panduan dzikir Asmaa-ul Husnaa. Kedua hal tersebut akan di proses melalui pengamalan dzikir Asmaa-ul Husnaa secara berkala, yaitu 2 kali pertemuan per minggu selama 4 minggu secara berjamaah. Namun diharapkan subjek dapat melakukan dzikir secara individual setiap hari. Output dari kegiatan tersebut adalah munculnya rasa ketentraman hati. Kondisi ini akan menyebabkan outcome berupa peningkatan kinerja.

\section{Pembahasan}

\section{Gambaran Perusahaan}

PT. Kharisma Export merupakan perusahaan yang bergerak di bidang industri manufaktur yang mengolah bahan baku kayu jati menjadi mebelair. Data perusahaan adalah sebagai berikut. Nama : PT. Kharisma Eksport

Alamat $\quad$ : Jl. Parangtritis Km 9.5 Tembi, Timbulharjo, Sewon, Bantul - Yogyakarta

Phone : $0274-368290$

Produksi : Eksport Furniture

Korespondensi : Endang Riwayatin

PT. Kharisma Export merupakan perusahaan yang bergerak di bidang eksport furniture. PT. Kharisma Export didirikan oleh Endang Riwayatin dan Raymond David pada tanggal 06 Mei 2002. Tanggal tersebut sesuai dengan tanggal yang tertera pada akte pendirian sekaligus dijadikan sebagai hari jadi.

\section{Karakteristik Responden}

Responden dalam penelitian ini merupakan karyawan dari PT Kharisma Export yang bersedia menjadi responden. Total karyawan yang bersedia menjadi responden adalah sebanyak 25 orang dari sekitar 500 karyawan. Dengan jenis kelamin 60\% pria dan $40 \%$ wanita. Dengan rentang usia antara 23 sampai dengan 50 tahun.

\section{Uji Reliabilitas dan Validitas}

Dari hasil uji reliabilitas yang dilakukan didapatkan nilai cronbach alpha 0,956, sehingga konstruk untuk penelitian ini adalah reliabel atau handal. Tabel hasil pengujian tersebut dapat dilihat pada Tabel 2 dan 3 .

Tabel 2. Summary Uji Reliabilitas Case Processing Summary

\begin{tabular}{|ll|l|l|}
\hline & & $\mathrm{N}$ & $\%$ \\
\hline Cases & Valid & 30 & 100.0 \\
& Excluded & & \\
& Total & 30 & .0 \\
& & 100.0 \\
\hline
\end{tabular}

a. Listwise deletion based on all variables in the procedure. 


\section{Tabel 3. Uji Reliabilitas}

Reliability Statistics

\begin{tabular}{|l|l|l|}
\hline & $\begin{array}{l}\text { Cronbach's Alpha } \\
\text { Based r on } \\
\text { Standardized }\end{array}$ & \\
Items & N of Items \\
\hline .956 & .959 & 15 \\
\hline
\end{tabular}

Dari hasil pengujian validitas di dapat score konstruk dengan hasil signifikan. Maka kuesioner tersebut valid.

\section{Analisis Deskriptif}

Untuk memberi gambaran atau deskripsi data dalam penelitian ini dilakukan analisis statistik deskriptif yang dapat terlihat pada Tabel 4.

1. Empat pertanyaan untuk Quality of work dapat dilihat pada tabel 4 pada soal A1 sampai A4.

2. Tiga pertanyaan untuk Quantity of work dapat dilihat pada tabel 4 pada soal B1 sampai B3.

3. Tiga pertanyaan untuk Job knowledge dapat dilihat pada tabel 4 dapat dilihat pada tabel C1 sampai C3.

4. Lima pertanyaan untuk Creativeness dapat dilihat pada tabel 4 dapat dilihat pada tabel D1 sampai D5.

Tabel 4. Hasil Uji Statistik Deskriptif

Item Statistics

\begin{tabular}{|l|l|l|l|}
\hline & Mean & Std. Deviation & N \\
\hline A1 & 3.30 & .651 & 30 \\
A2 & 2.90 & .548 & 30 \\
A3 & 3.30 & .651 & 30 \\
A4 & 2.90 & .548 & 30 \\
B1 & 3.10 & .845 & 30 \\
B2 & 3.50 & 1.042 & 30 \\
B3 & 3.20 & .887 & 30 \\
C1 & 3.40 & 1.037 & 30 \\
C2 & 2.60 & .814 & 30 \\
C3 & 3.00 & .788 & 30 \\
D1 & 3.60 & .932 & 30 \\
D2 & 3.10 & .845 & 30 \\
D3 & 3.40 & .814 & 30 \\
D4 & 2.90 & .548 & 30 \\
D5 & 3.20 & .610 & 30 \\
\hline
\end{tabular}

\section{Pengujian Asumsi Klasik}

\section{Uji Normalitas}

Uji Normalitas bertujuan untuk menguji apakah dalam model regresi, variabel pengganggu atau residual memiliki distribusi normal. Seperti diketahui bahwa uji t dan F mengasumsikan 
bahwa nilai residual mengikuti distribusi normal. Kalau asumsi ini dilanggar maka uji statistic menjadi tidak valid untuk jumlah sampel kecil.

Tabel 5. Hasil Uji Normalitas

One-Sample Kolmogorov-Smirnov Test

\begin{tabular}{|ll|l|}
\hline & & $\begin{array}{l}\text { Unstandardized } \\
\text { Residual }\end{array}$ \\
\hline $\mathrm{N}$ & & 30 \\
Normal Parametersa ${ }^{\mathrm{b}} \mathrm{b}$ & Mean & .0000000 \\
& Std. Deviation & 6.91776191 \\
Most Extreme Differences & Absolute & .184 \\
& Positive & .124 \\
& Negative & -.184 \\
Kolmogorov-Smirnov Z & & 1.010 \\
Asymp. Sig. (2-tailed) & & .259 \\
\hline
\end{tabular}

a. Test distribution is Normal.

b. Calculated from data.

Berdasarkan uji Kolmogorov-Smirnov menunjukkan hasil 1,010 dan signifikansi 0,259 hal ini berarti data residual terdistribusi normal.

\section{Uji Multikolinieritas}

Setelah dilakukan uji multikolinearitas, dihasilkan tabel sebagai berikut ini.

Tabel 6. Uji Multikolinieritas

\section{Coefficientsa}

\begin{tabular}{|ll|l|l|l|l|}
\hline \multirow{2}{*}{ Model } & \multicolumn{3}{|l|}{ Unstandardized Coefficients } & \multicolumn{2}{l|}{ Collinearity Statistics } \\
\cline { 3 - 6 } & & $\mathrm{B}$ & Std. Error & Tolerance & VIF \\
\hline 1 & (Constant) & 38.704 & 2.231 & & \\
& AMU & 1.426 & .299 & 1.000 & 1.000 \\
\hline
\end{tabular}

a. Dependent Variable: KNJ

Dari tabel 4.5 di atas terlihat bahwa besarnya nilai VIF variabel di bawah 10, hal ini menunjukkan bahwa dalam persamaan ini tidak terjadi multikolinieritas.

\section{Uji Heteroskedastisitas}

Dari grafik scatterplots terlihat bahwa titik-titik menyebar secara acak serta tersebar baik di atas maupun di bawah angka 0 pada sumbu Y. Hal ini dapat disimpulkan bahwa tidak terjadi heteroskedastisitas pada model regresi, sehingga model regresi layak dipakai untuk memprediksi kinerja (KNJ) berdasarkan masukan variabel independen pengamalan asmaa-ul husna (AMU). 


\section{Scatterplot}

Dependent Variable: KNJ

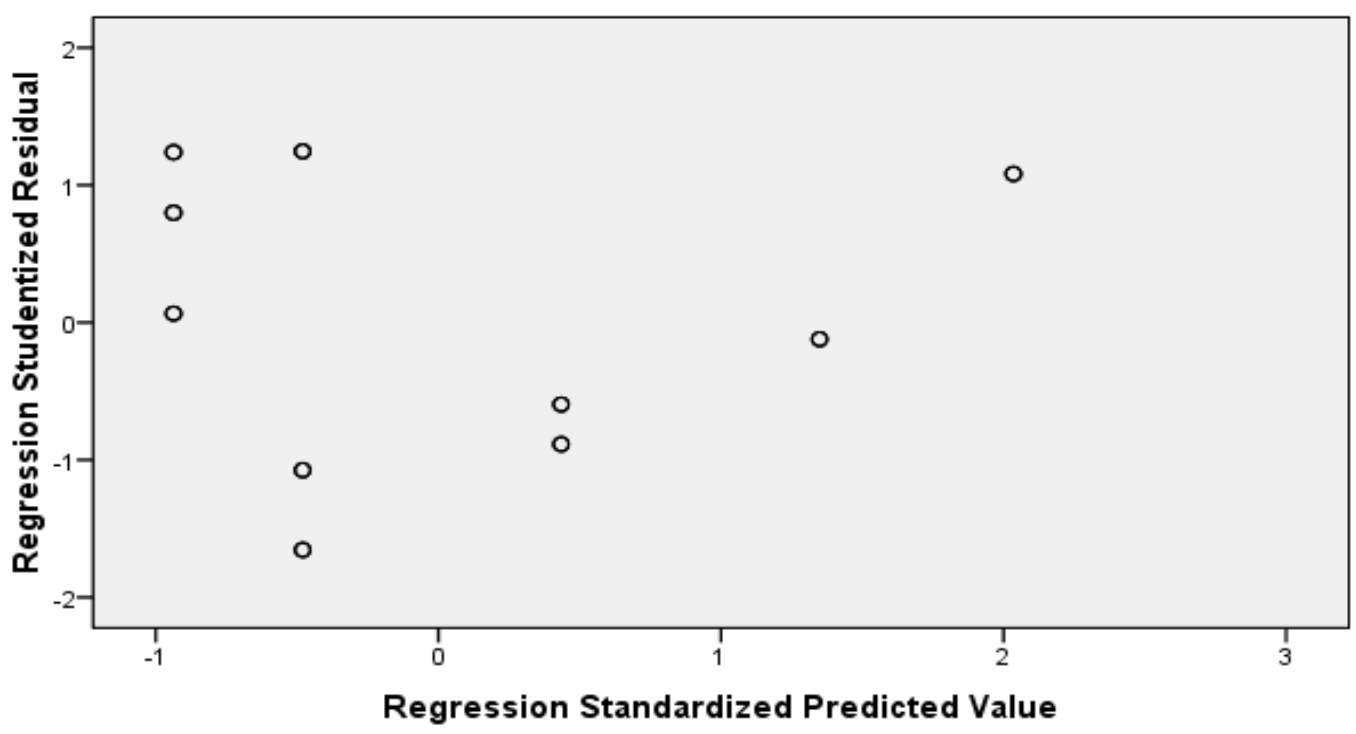

Gambar 2. Hasil Uji Heteroskedastisitas

\section{Analisis Regresi}

Penyelesaian model persamaan linier berganda dengan bantuan program SPSS 17.0 menghasilkan Tabel 7berikut ini.

Tabel 7. Hasil Analisis Regresi

Coefficients $^{\mathrm{a}}$

\begin{tabular}{|c|c|c|c|c|c|}
\hline \multirow[b]{2}{*}{ Model } & \multicolumn{2}{|c|}{$\begin{array}{l}\text { Unstandardized } \\
\text { Coefficients }\end{array}$} & \multirow{2}{*}{$\begin{array}{l}\text { Standardized } \\
\text { Coefficients } \\
\text { Beta }\end{array}$} & \multirow[b]{2}{*}{$\mathrm{T}$} & \multirow[b]{2}{*}{ Sig. } \\
\hline & $\mathrm{B}$ & Std. Error & & & \\
\hline $1 \quad$ (Constant) & 38.704 & 2.231 & & 17.349 & .000 \\
\hline AMU & 1.426 & 299 & .670 & 4.769 & .000 \\
\hline
\end{tabular}

Dari hasil analisis, maka model yang diperoleh untuk menunjukkan pengaruh dzikir Asmaa-ul Husna terhadap Kinerja adalah sebagai berikut.

\section{$Y=38,704+1,426 X$}

Dari hasil perhitungan regresi didapatkan hasil konstanta sebesar 38,704 hal ini menunjukkan bahwa apabila variabel Asmaa-ul Husna konstan maka nilai kinerja akan mencapai 40,130. Variabel pengamalan dzikir Asmaa-ul Husna memiliki koefisien sebesar 1,426 dengan arah positif.

\section{Analisis Hipotesis dan Pembahasan}

\section{Uji Simultan (Uji F)}

Uji F digunakan untuk menunjukkan apakah semua variabel bebas (independen) yang dimasukkan ke dalam model memiliki pengaruh secara bersama-sama atau simultan terhadap variabel terikat (dependen). Cara yang digunakan adalah dengan melihat besarnya nilai proba- 
bilitas signifikansinya. Jika nilai probabilitas signifikansinya kurang dari 5\% maka variabel independen akan mempengaruhi variabel dependen.

Hasil analisis uji F, disajikan dalam Tabel 8 berikut.

Tabel 8 Hasil Analisis Uji F

ANOVA $^{b}$

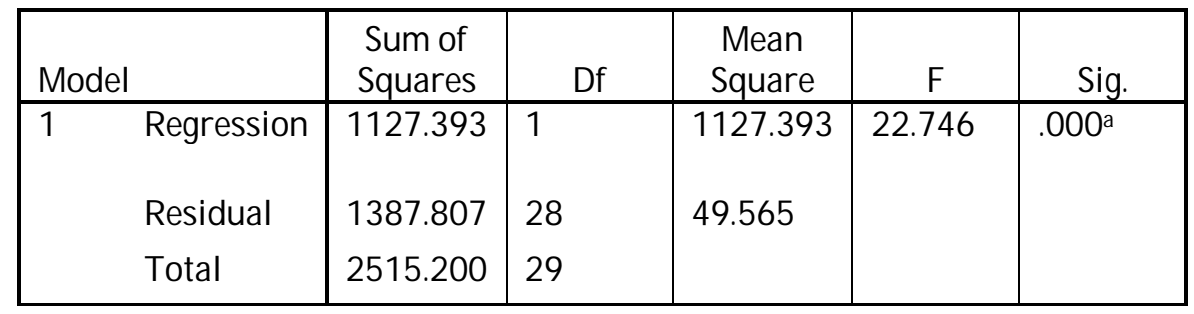

Berdasarkan hasil uji anova atau F test, didapat F hitung sebesar 22,277 dengan tingkat probabilitas 0,000 (signifikan). Karena probabilitasnya lebih kecil daripada 0,05 atau 5\% maka model regresi dapat digunakan untuk memprediksi kinerja.

\section{Uji Parsial (Uji t)}

Uji parsial atau uji t ini digunakan untuk mengetahui apakah masing-masing variabel independen berpengaruh terhadap variabel dependen. Pengambilan keputusan dilakukan b tabel berdasarkan perbandingan nilai $t_{\text {hitung }}$ masing-masing koefisien dengan $t_{\text {tabel, }}$ dengan tingkat signifikansinya $5 \%$. Jika $t_{\text {hitung }}<t_{\text {tabel }}$ maka H0 diterima, ini berarti variabel independen tidak berpengaruh terhadap variabel dependen. Sedangkan jika $t_{\text {hitung }}>t_{\text {tabel }}$ maka H0 ditolak dan menerima Ha, ini berarti variabel independen berpengaruh terhadap variabel dependen. Hasil analisis uji t disajikan dalam Tabel 9.

Tabel 9 Hasil Uji Parsial

Coefficients $^{\mathrm{a}}$

\begin{tabular}{|c|c|c|c|c|c|}
\hline \multirow[b]{2}{*}{ Model } & \multicolumn{2}{|c|}{$\begin{array}{l}\text { Unstandardized } \\
\text { Coefficients }\end{array}$} & \multirow{2}{*}{$\begin{array}{l}\text { Standardized } \\
\text { Coefficients } \\
\text { Beta }\end{array}$} & \multirow[b]{2}{*}{$\mathrm{T}$} & \multirow[b]{2}{*}{ Sig. } \\
\hline & B & Std. Error & & & \\
\hline 1 (Constant) & 38.704 & 2.231 & & 17.349 & .000 \\
\hline AMU & 1.426 & 299 & .670 & 4.769 & .000 \\
\hline
\end{tabular}

Berdasarkan hasil olah data, variabel pengamalan Asmaa-ul Husna mempunyai thitung sebesar 4,769 dengan nilai signifikansinya 0,0\%. Berdasarkan tabel t dan $\mathrm{r}$ product moment untuk degree of freedom (df) 28 yang dihitung berdasarkan jumlah sample dikurangi 2, yaitu 30-2=28, didapat $t_{\text {tabel }}$ sebesar 2,0484. Karena $t_{\text {hitung }}<t_{\text {tabel }}$ maka Ha ditolak dan menerima H0.

\section{Koefisien Determinasi ( $\left.\mathbf{R}^{2}\right)$}

Hasil perhitungan yang dilakukan peneliti dengan menggunakan bantuan program SPSS menunjukkan bahwa nilai adjusted $\mathrm{R}^{2}$ adalah sebesar 0,429 atau 42,9\%. Hal ini menjelaskan bahwa variabel-variabel independen yang dimasukkan dalam model regresi ini mampu menjelaskan pengaruh terhadap variabel independen sebesar $42,9 \%$ sedangkan sisanya sebesar $57,1 \%$ dijelaskan oleh faktor lain. 
Tabel 10 Hasil Uji Koefisien Determinasi

Model Summary

\begin{tabular}{|l|c|l|l|l|}
\hline Model & $\mathrm{R}$ & $\begin{array}{c}\mathrm{R} \\
\text { Square }\end{array}$ & $\begin{array}{c}\text { Adjusted } \mathrm{R} \\
\text { Square }\end{array}$ & $\begin{array}{c}\text { Std. Error of the } \\
\text { Estimate }\end{array}$ \\
\hline 1 & $.670^{\mathrm{a}}$ & .448 & .429 & 7.040 \\
\hline
\end{tabular}

\section{Pembahasan}

Dari hasil pengujian dapat disimpulkan bahwa pengamalan dzikir Asmaaul Husna berpengaruh terhadap kinerja. Tata cara pengamalan dzikir ini akan memiliki dampak yang signifikan jika dzikir dilakukan secara rutin. Semakin rutin dilakukan maka dampaknya akan semakin dapat dirasakan. Selain itu juga dari jumlah bacaan, yang jumlah bacaannya lebih dari satu kali akan merasakan manfaat yang lebih besar jika dibandingkan yang hanya 1 kali, demikian juga yang sudah mengamalkan lebih dari 1 tahun secara rutin akan berbeda dengan yang baru mengamalkan 2 bulan atau 1 tahun.

Penulis menanyakan kepada beberapa responden mengenai apa yang dirasakan ketika melakukan dzikir dan setelahnya:

Responden 1 : "Enak mba.. rasanya rileks kadang sampai mengantuk... hehehe" (sambil tertawa kecil)"

Responden 2 : "Adeem.."

Responden 3 : "Lupa semua beban.. trus abis itu jadi semangat.. kayanya aku jadi lebih pintar deh.."

Dari testimoni tersebut menunjukkan bahwa efek ketenangan dari pengamalan dzikir ini dirasakan oleh para responden sehingga dapat berpikir dan bekerja dengan tenang. Mereka merasakan tingkat kepasrahan yang tinggi terhadap Tuhan Yang Maha Esa.

Selain perasaan tenang yang dirasakan para responden, juga dirasakan dampak lain yaitu terkait dengan kemampuan dan kecerdasan dalam menangani masalah dan dalam pergaulan, seperti dalam kutipan berikut ini:

Responden 1: "Rasanya jalannya banyak terbuka, lebih mantap menjalani kehidupan.. ohya mungkin lebih enak lagi kalo diamalin pas tahajud kali ya.. hehehe.. lebih dahsyat"

Responden 2: "kaya ditatain hidupnya mba.."

Responden 3: "Urusanku jadi lancer mba.. hati jadi tenang..”

Dengan demikian, pengamalan dzikir asmaa-ul husna membawa dampak positif bagi ketenangan diri dan kinerja.

\section{PENUTUP}

\section{Kesimpulan}

Berdasarkan hasil penelitian dapat diketahui bahwa pengamalan dzikir Asmaa-ul Husna berpengaruh terhadap kinerja. Hal ini diperkuat dengan beberapa testimoni dari para responden sehingga dapat disimpulkan seperti berikut.

1. Pengamalan dzikir Asmaa-Ul Husna mempengaruhi kinerja dari aspek Quantity of Work, Quality of Work,Job Knowledge, Creativity.

2. Tingkat rutin atau tidaknya pengamalan, banyaknya bacaan dan jangka waktu pengamalan mempengaruhi kinerja. 
Hasil dari penelitian ini dapat dijadikan gambaran bahwa aspek religi menjadi bagian yang sangat penting dalam sendi kehidupan khususnya dalam hal penyajian hasil kerja yang meningkat dari waktu ke waktu.

\section{Saran}

Penelitian ini belum memasukkan beberapa aspek yang kemungkinan menjadi faktor yang dapat lebih memaksimalkan hasil pengamalan, yaitu seperti berikut.

1. Keikhlasan, keikhlasan dapat menjadi pendorong yang sangat bagus di dalam beribadah, karena tanpa keikhlasan maka akan sulit mendapatkan kekhusukan.

2. Kekhusukan, kekhusukan menjadi hal yang sangat dibutuhkan dalam beribadah, karena dalam kondisi khusu terdapat konektivitas yang baik antara hamba dengan Sang Khalik.

3. Waktu Mustajab, Alloh memberikan isyarat untuk waktu-waktu mustajab di dalam berdoa. Dengan mengambil pelajaran ini maka doa akan menjadi lebih mustajab.

Dengan demikian diharapkan pada penelitian selanjutnya dalam memasukkan aspek ini ke dalam variabel dependennya.

\section{DAFTAR PUSTAKA}

Al Hafidh dan Amdjad. 2014. Keistimewaan dan Peranan Al Asmaa-ul Husnaa di Zaman Modern. Semarang: Sufijaya.

Antonio, Syafii. 2008. Muhammad Super Leader Super Manager. Bogor: Tazkia Publishing.

Dahlan. 2009. Statistik Untuk Kedokteran dan Kesehatan. Jakarta: Penerbit Salemba Medika.

Ghozali, I. 2011. Aplikasi Analisis Multivariate dengan Program SPSS. Semarang: Badan Penerbit Universitas Diponegoro.

Gomes. 2003. Manajemen Sumber Daya Manusia. Yogyakarta: Andi Offset.

Kementrian Agama RI. 2012. Al Qur’an Nur Karim. Jakarta: Kementrian Agama RI.

Prawirosentono, Suyadi. 1999. Kebijakan Kinerja Karyawan. Yogyakarta: BPFE.

Priansa, Donni. 2014. Perencanaan dan Pengembangan SDM. Bandung: Alfabeta.

Riani, A., L. 2013. Manajemen Sumber Daya Manusia Masa Kini. Yogyakarta: Graha Ilmu.

Riani, Asri Laksmini. 2011. Budaya Organisasi. Yogyakarta: Graha Ilmu.

Sulaiman al-Asyqar dan Umar. 2010. Edisi Indonesia: Al-Asma' al-Husna.Jakarta: Qisthi Press.

Umar, Husein. 2002. Evaluasi Kinerja Perusahaan. Jakarta: Gramedia Pustaka Utama. 